Liberty and the News 


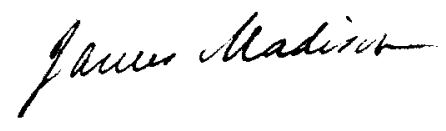

THE JAMES MADISON LIBRARY IN AMERICAN POLITICS

Sean Wilentz, General Editor

The James Madison Library in American Politics of the Princeton University Press is devoted to reviving important American political writings of the recent and distant past. American politics has produced an abundance of important works-proclaiming ideas, describing candidates, explaining the inner workings of government, and analyzing political campaigns. This literature includes partisan and philosophical manifestos, pamphlets of practical political theory, muckraking exposés, autobiographies, on-the-scene reportage, and more. The James Madison Library issues fresh editions of both classic and now-neglected titles that helped shape the American political landscape. Up-to-date commentaries in each volume by leading scholars, journalists, and political figures make the books accessible to modern readers.

The Conscience of a Conservative by Barry M. Goldwater

The New Industrial State by John Kenneth Galbraith

Liberty and the News by Walter Lippmann

The Politics of Hope and The Bitter Heritage: American Liberalism in the 1960 s by Arthur M. Schlesinger, Jr. 


\section{Liberty and the News}

\section{Walter Lippmann}

With a new foreword by Ronald Steel

and a new afterword by Sidney Blumenthal 
General Editor's Introduction Copyright (C) 2008 by Sean Wilentz Foreword Copyright @ 2008 by Princeton University Press Afterword Copyright $(\mathcal{C} 2008$ by Sidney Blumenthal

Requests for permission to reproduce material from this work should be sent to Permissions, Princeton University Press

Published by Princeton University Press, 41 William Street, Princeton, New Jersey 08540

In the United Kingdom: Princeton University Press, 3 Market Place, Woodstock, Oxfordshire OX20 1SY

All Rights Reserved

First published 1920

First Princeton paperback edition, 2008

Library of Congress Control Number 2007932924

ISBN 978-0-691-13480-2

British Library Cataloging-in-Publication Data is available

This book has been composed in Sabon with Helvetica Neue and

Didot display

Printed on acid-free paper. $\infty$

press.princeton.edu

Printed in the United States of America

10987654321 